\title{
The Appearance of Bricks in Ancient Mesopotamia
}

\author{
By Kadim Hasson Hnaihen*
}

\begin{abstract}
Mesopotamia is a region in the Middle East, situated in a basin between two big riversthe Tigris and the Euphrates. About 5,500 years ago, much earlier than in Egypt, ancient civilization began, one of the oldest in the world. Continuous development was an important factor of everyday life. A warm climate, fertile soil, mixed with the sediment of flowing rivers and perhaps even the first oak all. A deficit of stone for building shelter was an impediment that the Sumerians faced, but from this shortage they found the perfect solution for their construction-brick. Shelter, homes and other buildings were built from material available in the area, such as clay, cane, soil, mule. Sumerians mastered the art of civic construction perfectly. They raised great buildings, made of bricks (Ziggurats, temples, and palaces) richly decorated with sculptures and mosaics. In this article I will focus on the most interesting time period in my opinionwhen brick appeared, I will comment upon the process of production and the types of the brick used in Mesopotamia. It should be noted that the form we know today has been shaped by the cultural and social influences of many peoples who have successively settled these lands, continuing to a large extent the cultural heritage of the former.
\end{abstract}

\section{Introduction}

The ancient population of Iraq (from the Stone Age, 150,000 BC to 8,000 BC) inhabiting Mesopotamia is one of the oldest civilizations to be discovered. They were Old Stone Age (Paleolithic) (150,000 BC to 12,000 BC): About 100,000 years ago, people lived in caves in northern Iraq and used stones for the manufacture of their instruments. The oldest caves are Zerzi cave, Hazar Murd cave in Sulaymaniyah city. ${ }^{1}$ The dimensions of one of the well-known caves "Shanider" in Zagros Mountains, is 25 metres wide, the entrance to the cave is 8 metres high. It is 40 metres long and 53 metres wide from the inside. ${ }^{2}$ Clay brick masonry is one of the oldest and most durable construction techniques used by mankind. It was a fundamental building material in the Mesopotamian, Egyptian periods. Despite several modifications of the clay brick uses, shape and manufacture along thousands of years of continuous evolution, the simplicity that made it successful remained the simple manufacturing process based on fired clay, a raw material available in large quantities all over the Earth. Its wide use proved that the clay

*PhD Student, University of Warsaw, Poland.

1. Seaid Alrwishdi, "Caves in the Middle East" [in Arabic], Sumer 25 (1969): 261; Najel K. Abd Alrazaq, "The planning and design characteristics of buildings and mud settlements in Iraq" [in Arabic], Journal Planner and Development 25 (2012): 94.

2. Entidhar Al-Taie, Nadhir Al-Ansari, and Sven Knutsson, "Progress of building materials and foundation engineering in ancient Iraq," Advanced Materials Research 446-449 (2012): 222. 
brick was an effective construction material that could provide both resistance to prevalent climatic conditions and insulation from both cold and heat. It is known that the properties of ancient clay brick masonry rely essentially on the properties of the brick units, which depend on the quality of the raw materials used, together with the manufacturing process technology. The analysis of clay brick production and final properties are therefore fundamental. Generally, it is crucial to obtain information on the main physical, chemical and mechanical properties of clay bricks as well as the characteristics of the raw materials used and their manufacturing process. ${ }^{3}$ Clay bricks are products of a dough consisting of clay soil and water, pure clay or a mix with other materials such as straw. Bricks were formed primitively, naturally dried and fired in the kilns in the workshop. ${ }^{4}$ As we know clay bricks were widely used in ceilings because they were manageable to prepare, they were lighter than stones, able to be aligned in rows, and they were possibly used with a lightweight mold. ${ }^{5}$ Soil is a cheap and abundantly available building material on the Mesopotamian land. ${ }^{6}$ The properties of clay had been noticed very fast and began mixing with other available materials to improve brick and get new useful mechanical properties, which are more frequently retrieved in the case of the composite material properties. ${ }^{7}$

3. Francisco M. Fernandes, Paulo B. Lourenço, and Fernando Castro, "Ancient Clay Bricks: Manufacture and Properties," in Materials, Technologies and Practice in Historic Heritage Structures, ed. Maria Boştenaru Dan and Richard Přikryl (Dordrecht: Springer, 2010), 2.

4. N. Volkan Gür, Ömer Ş. Deniz, and Savas Ekinci, "Carrier Materials and Components in Masonry Masonry" (presentation, 6th National Roof \& Facade Symposium, Faculty of Engineering and Architecture, Uludağ University, Bursa, Turkey, April 12-13, 2012), 5. Retrieved from https://bit.ly/30X9sYG.

5. Aysil Tukel Yavuz, "The Relationship between Materials and Architecture in the Seljuk Period" (presentation, Material and Architecture Symposium in Anatolia from the Past to the Future, UIAXXII World Architecture Congress, 2005), 79.

6. Kebao B. Ren and Douglas A. Kagi, "Upgrading the durability of mud bricks by impregnation," Build Environment 30, no. 3 (1995): 433-440; Neslihan Dalkılıç and Adnan Nabikoğlu, "Traditional manufacturing of clay brick used in the historical buildings of Diyarbakir," Frontiers of Architectural Research 6, no. 3 (2017): 346-59.

7. Tomas Wijffels and G. Nijland Timo, "Deterioration of historic brick masonry due to combined gypsum, ettringite and thaumasite, a case study" (presentation, 13th International Brick/Block Masonry Conference, Amsterdam, 2004), 89. 


\section{History of Bricks}

Nemrik, a pre-pottery Neolithic village $55 \mathrm{~km}$ northwest of Mosul, now provides the earliest architectural sequence for northern Mesopotamia (Figure 1). In the oldest, ninth-millennium settlement, taut-walls were built of variously sized "blocks," $20 \mathrm{~cm}$ thick on average. In the eighth-millennium phase "the walls...consisted of a single thickness of cigar-shaped sun-dried mud bricks,

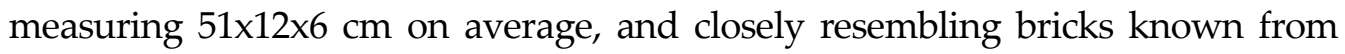
much later Mesopotamian sites such as Choga Mami and Oueili."8 In the seventh millennium, walls were built either entirely of sun-dried mud bricks or of a combination of bricks and pack clay (taut). Hand-shaped sun-dried mud bricks appeared in settlements on the line of the Euphrates, at locations such as Bouqras and Ramad, by at least the second half of the seventh millennium BC. Primitive bricks may be observed over the next thousand years in sites such as Matarrah, Shemshara, Umm Dabaghiyah, and Yarim Tepe I in northern Mesopotamia. Moulded sun-dried mud bricks, regardless of the precise stage of their earliest development, begin to be widely evident in the Hassuna/Halaf/Samarra/ Ubaid I cultural horizons in the second half of the millennium BC, in the north and south.

The mud bricks of Ubaid I and the early levels at Tell el-Oueili in the south are of the cigar- and loaf-shape well known in Khuzistan, where they were already employed at Choga Bonut. "Archaic 1," and at Tell es-Sawwan and Choga Mami. ${ }^{9}$ At Oueili there appears to be continuity in their use through to Ubaid 4 . This use of loaf-shaped bricks is best taken as an evolutionary stage in the development of mud-brick building rather than as a necessary sign of cultural unity. The basic limitations of architecture of terre pise had a profound long-term effect on the builders of ancient Mesopotamia. The laws of gravity and the quality of the workmanship in foundation setting and in ramming techniques determine the relationship between the height and width in packed earth walls. Terre pise tends to be unstable. Certain fundamental inhibitions survived the introduction of pre-dried and standardized bricks, which made walls lighter and thus capable of being built taller so long as the points and lines of stress were appropriately treated. The real key lay in the proper use of mortar and kiln-fired bricks. In general, as with terre pise, the methods of making sun-dried moulded mud bricks (libn) that evolved in remote antiquity have endured in Iraq substantially

8. Stefan K. Kozlowski and Andrzej Kempisty, "Architecture of the Pre-Pottery Neolithic Settlement in Nemrik, Iraq," World Archaeology 21, no. 3 (1990): 353.

9. Joan Oates, "The Choga Mami Transitional," in La Prehistoire de la Mesopotamie, ed. Jean-Louis Huot (Paris: Editions du CNRS, 1987): 164; Martin Sauvage, "Les briques de grande taille à empreintes de doigts: le Choga Mami Transitional et la culture de Oueili" (Large bricks with fingerprints: the Choga Mami Transitional and the culture of Oueili), in Études mésopotamiennes: Recueil de textes offert à Jean-Louis Huot (Mesopotamian Studies: A collection of texts offered to Jean-Louis Huot), ed. Catherine Képinski and Christine Brenniquet (Paris: ERC, 2001), 417. 
unchanged, as examination of surviving bricks and the witness of texts relating directly to the manufacture of bricks makes clear. Aurenche ${ }^{10}$ has given a detailed review of techniques, whilst Salonen ${ }^{11}$ provided a useful series of pictures of brickmaking in modern communities in comparable regions.

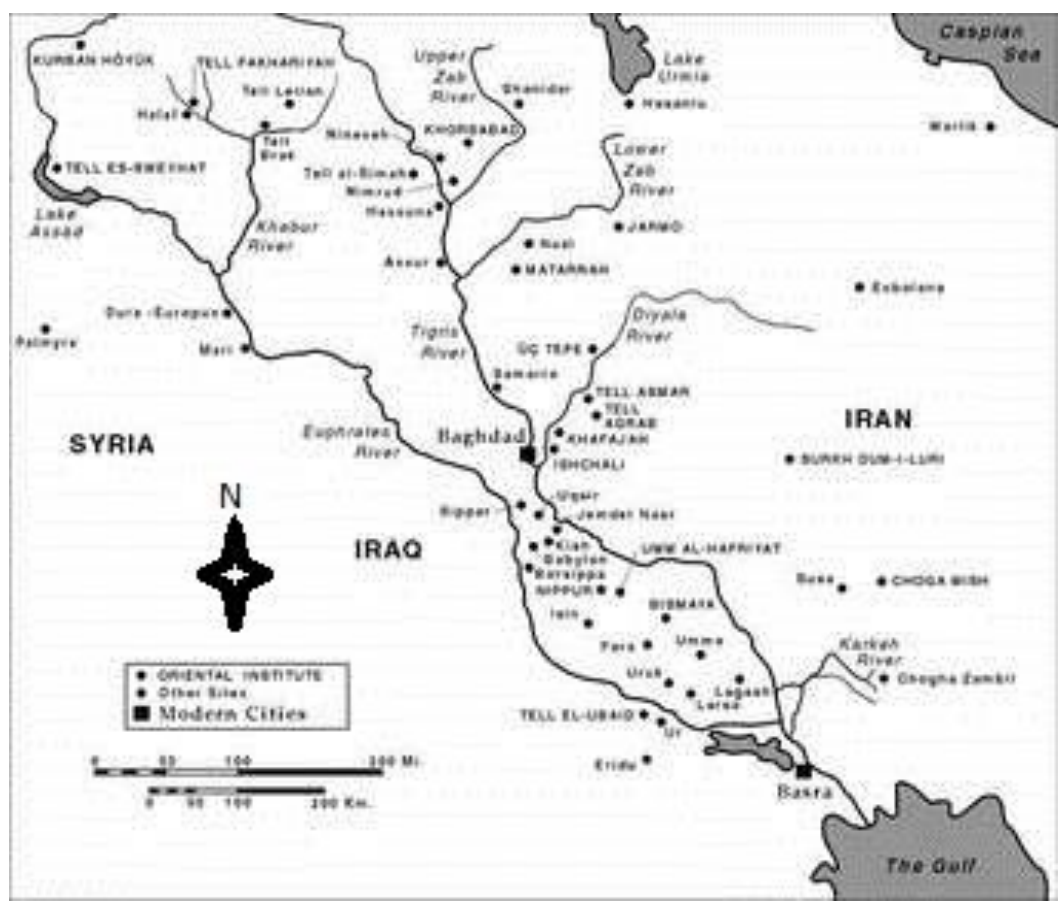

Figure 1. Map of Mesopotamia Archeological Sites

Source: Oriental Institute, University of Chicago. Retrieved from https://ces.to/Pyq9oG.

Mud bricks were commonly produced in rectangular wooden moulds, open at the top and bottom, usually singly, but sometimes in twos or threes. Almost any soil may be used as the medium, though one with a greater clay content is more satisfactory. Some form of tempering was always necessary to avoid warping and cracking. Chopped straw or dung was most commonly used. It has been calculated ${ }^{12}$ that 100 bricks require about $60 \mathrm{~kg}$ of straw (i.e., Y. hectare of barley). The resistance of sun-dried mud bricks to fracture decreases with the decay of the straw bonding. Pulverized sherds and other mineral matter were

10. Olivier Aurenche, La Maison Orientale, L'architecture du proche orient ancien des origines au milieu du quatrieme millenaire (The Oriental House, The architecture of the ancient Near East origins in the middle of the fourth millennium) (Paris: French Institute of Archeology of the Middle East; Beirut, Damascus Amman: Archaeological and Historical Library, 1981), 64 .

11. Armas Salonen, Die Ziegeleien im alten Mesopotamien (The brickworks in ancient Mesopotamia) (Helsinki: Finnish Academy of Sciences, 1972), XXXVIII-LII.

12. David Oates, "Innovations in Mud-Brick, Decorative and Structural Techniques in Ancient Mesopotamia," World Archaeology 21, no. 3 (1990): 390. 
sometimes employed. The lime content of many clays in Iraq make them particularly suitable for the manufacture of durable mud bricks. There is no evidence that bitumen was incorporated in the clay mix in antiquity, though it has been in recent experiments. When kings were involved in formal ceremonies at the start of a building project, ivory tools and precious wood equipment was employed. The making and laying of bricks for public buildings, especially temples, is known from textual sources to have been accompanied by ceremonies and rituals to propitiate the gods, including a specific brick god, and to create the most favorable circumstances, especially for the crucial process of making the first brick. ${ }^{13}$ For each new project unbaked mud bricks had to be freshly made, as they cannot be salvaged from old buildings. Written evidence indicates that such rituals accompanied work on basic dwellings as well.

Bricks are unique among Mesopotamian artifacts "because they are the only surviving artifact for which textual evidence attests that they incorporate norms of length, area, volume, capacity and weight-a rather remarkable combination in the history of pre-modern metrology." However, there already exists extensive literature on the mathematical aspects of quantity assessment and related brick problems based on the surviving documentary evidence. ${ }^{14}$ Bricks were used in enormous quantities, especially for the platforms or rafts of mud brick which replaced trench foundations in the Neo-Assyrian period, and always for Ziggurats. Virtually nothing is known archaeologically of brick kilns in ancient Mesopotamia; even in Egypt pictorial evidence is rare. ${ }^{15}$ Below the "Stone Cone Temple" at Uruk a concentration of what may be late prehistoric brick kilns was excavated, many apparently used only once, to produce bricks measuring $32 X I 8 X 9 \mathrm{~cm} .{ }^{16}$ Others have been claimed at Khafajah ${ }^{17}$ and Nuzi. It is commonly assumed that they differed little from their more primitive modern counterparts evident throughout the Iraqi countryside. ${ }^{18}$

By the Ubaid period they may be observed in use from Gawra level XIII in the north southwards to Eridu. ${ }^{19}$ The figures for brick sizes reveal both an increasing standardization and a reduction in size. For the first time bricks no

13. Peter Roger Stuart Moorey, Ancient Mesopotamian Materials and Industries, The Archaeological Evidence (Oxford: Clarendon Press, 1994), 311.

14. Marvin A. Powell, "Metrological Notes on the Esagila Tablet and Related Matters, Appendix II, Bricks as Evidence for Metrology," Zeitschrift fur Assyriologie 72 (1982): 117.

15. Ursula Verhoeven, "Eine technologische Rarität. Das Brennen von Ziegeln in der Grabdekoration des Mittleren und Neuen Reiches" (A technological rarity. The burning of bricks in the grave decoration of the Middle and New Kingdom), Communications of the German Archaeological Institute, Department of Cairo, 43 (1987), 261.

16. Moorey, Ancient Mesopotamian, 311.

17. Henri Frankfort, The Art and Architecture of the Ancient Orient (Chicago: Penguin Books, 1970), 76.

18. Salonen, Die Ziegeleien im alten Mesopotamien, 119.

19. Aurenche, La Maison Orientale, 67, table 6 (with dimensions), map 6. 
more than $50 \mathrm{~cm}$ long are more common than larger ones. On ethnographical analogies Aurenche interprets this as indicative of molding. In discussing the bricks used in temples of the Ubaid period at Uruk, it was observed that even if the technique of brick manufacture was still primitive, regular form and size (4542X24-22X87 cm) indicated organized mass-production. Moorey implied a very similar conclusion in his discussion of brickwork in the shrines of Gawra XIII. ${ }^{20}$ The emergence of the widely distributed "tripartite" plan for houses and temples in the Ubaid period reinforces the argument that new levels of social organization now affected the builder's craft across the whole of Mesopotamia.

No baked bricks have yet been reported before the Uruk period, apart from an anomalous instance in Gawra XIII. A find in the Eastern Shrine "consisted of a total of ninety-nine model bricks made of well-baked terracotta... Examples of full bricks, square half bricks, long half bricks, and quarter bricks were represented... Apparently these model bricks were used to determine the most satisfactory method of bonding and building the complicated recessed piers and pilasters found in Stratum XIII structures" (No baked bricks have yet been reported before the Uruk period, save for an anomalous instance in Gawra XIII. A find in the Eastern Shrine "consisted of a total of ninety-nine model bricks made of wellbaked terracotta... Examples of full bricks, square half bricks, long half bricks, and quarter bricks were represented... Apparently these model bricks were used to determine the most satisfactory method of bonding and building the complicated recessed piers and pilasters found in Stratum XIII structures."21 Up to the middle of the fourth millennium BC moulded mud bricks had tended to be large and flat. In the Uruk period smaller proportions emerged so that two bricks could be handled together. Now, also for the first time, bricks were baked in kilns for special purposes and shapes were varied to suit functions in a building. Finkbeiner has provided a full review of the brick-shapes used at Uruk through the later prehistoric levels (VIIIVI-I). ${ }^{22}$

The preferred brick manufacturing month was the "third" (May-June), immediately after the spring rains, when water would be plentiful and the whole summer lay ahead, if necessary, for drying. Chaff or straw was easily available at this time. The July-August period was characterized as a time of building, ness of the ground would have facilitated foundation laying. The association of the firegod with building may arise from this conjunction of intense heat and construction. ${ }^{23}$ Broadly speaking, as with terre pise, the methods of making sundried moulded mud bricks (libn) evolved in remote antiquity have endured in

20. Moorey, Ancient Mesopotamian, 312.

21. Moorey, 314.

22. Uwe Finkbeiner, "Uruk-Warka, Evidence of the Gamdat Nasr Period," in Gamdat Nasr: Period or Regional Style?, ed. Uwe Finkbeiner and Wolfgang Röllig (Wiesbaden: Reichert, 1986), $47 \mathrm{ft}$. , appendix II lists brick sizes.

23. Richard S. Ellis, Foundation Deposits in Ancient Mesopotamia (New Haven Londres: Yale University Press, 1968), 20. 
Iraq substantially unchanged, as an examination of surviving bricks and the evidence within texts relating directly to the manufacture of bricks makes clear.

\section{Methodology}

A general lack of interest in the essential building elements in Mesopotamia; namely - brick, was a reason for me to take an interest in following this topic. Furthermore, from my work I am able to postulate a new theory about the process of brick production, types and calculations of their dimensions in the area of Ancient Iraq where the only one who took the topic of research of bricks, the process of their formation was Sir Al-Temimi, who dealt with the topic of production of the brick in ancient Iraq. ${ }^{24}$ According to my research, we are able to calculate the amount of brick by using the dimensions of brick (length, width and height) for each wall, by drawing them and calculating according to the figure to one spatial meter. ${ }^{25}$

Thanks to the wedge inscription, we will find out that the time needed to dry a brick is one or two days depending on the season of the year. The clay fermentation time is one day. At the same time, it is required that the water that is used to make the brick burnt clean than that which used to prepare the dried brick. ${ }^{26}$ Moreover, at the same time, we know thanks to the next inscription that the pores of producing brick is from the middle of March where the rainy season is now half way through October when the weather is changing, as well as the months in which the ancient inhabitants of Mesopotamia begin to produce brick are called months of clay location in the templates. Thanks to this information, we already know what the elements are and the time that is needed to make up the brick as well as the period of its production. At the same time, I have learnt the stages and types of bricks that could have come from them throughout history. It can be said that brick is not only of fundamental importance in building cities but also that it was an important economic element, because we know that the price of production of 370 burnt bricks plus their transport from the place of production to the construction site was equal to 1 shekel of silver and 1 shekel silver equals 8.4 grams. ${ }^{27}$

24. Abas A. Al-Temimi, "Mud Bricks in Ancient Iraq, Production and Patterns" [in Arabic], Sumer 38 (1982): 278.

25. Number of bricks to $\mathrm{m}^{3}$ convert according to dimensions of bricks in space meters with two $\mathrm{cm}$ added to the height of each brick which represents the clay connecting bricks in the wall.

26. Fuozi Rashid, "Brick production in Ancient Iraq" [in Arabic], Oil and Development, Development in Iraq for centuries 87 (1981): 45.

27. Rashid, "Brick production in Ancient Iraq," 36. 


\section{The Productions of Bricks in 4th and 3rd Millennium BC}

It is a curiosity that brick is still produced with ancient technology. General production phrases are: Raw material preparation, forming, drying, fringing, packing and dispatch. The next step of the brick's production was using clay where it was made in regular sun-dried sticks, in contrast to the previous clay used in construction which was soft. After using the clay as the basic material from which structures and buildings were made, before finally, dried brick arrived as a new material. There were problems in the south of Mesopotamia where dry bricks did not meet the building requirements, because it was irresistible to moisture, in addition to the high groundwater levels in the area, the lack of stone and the difficulty of carrying it out of northern Mesopotamia. At the same time, people already knew ceramics and its properties that were resistant to moisture, so the builders began to burn bricks before being built, and thereby appeared burnt bricks with new properties such as being resistant to humidity. Moreover, for the first time evidence of the baked brick appeared during the Uruk period, and exactly in the buildings of Eridu city. ${ }^{28}$ According to Mr. Hussin, excavations in Ur discovered burnt bricks with inscribed information about the inhabitants of Ur during the Uruk period, and building a palace in dry brick chisel used clay to merge brick and its road was built of fired-brick in 3500 BC. ${ }^{29}$

The ancient inhabitants of Mesopotamia were interested in the production of bricks. They mastered the quality and method of interest in the mud fermentation process, and the method of firing bricks to get a uniform brick fired by using closed furnaces to maintain the correct temperature. It adversities the ability to oppose environmental factors.

The contribution of kings to the construction of temples, Ziggurats and palaces was also influenced by the contribution of kings to the construction of temples, Ziggurats and palaces. For example, we can see King Ur-Nansha (Figure 2) the founder of the first Dynasty of Lagash, where a basket of clay is produced to produce dried or burned bricks. ${ }^{30}$ We really have a lot of monuments where the kings' contributions are made in building or making bricks, where they wore them on their heads in clay-filled baskets, just like UrNammu (Figure 3). ${ }^{31}$ At the same time, we have a letter in the wedge that tells

28. Al-Temimi, "Mud Bricks in Ancient Iraq," 277.

29. Setar H. Hussain, "Ways to produce bricks and its type" [in Arabic], Sumer 43, no. 1 (1984): 258; Mohammed Ali Mustava and Seaid Alrwishdi, Fired brick production [in Arabic] (Baghdad: General Directorate of Ancient Monuments, 1992).

30. Seton Lloyd, The Archaeology of Mesopotamia, From the Old Stone Age to the Persian Conquest, trans. Al-Ahmed Samy (Baghdad: Notional Hause Production, 1980), 133, figure 68.

31. Jeanny Vorys Canby, "A Monumental Puzzle Reconstructing the Ur-Nammu Stela," Expedition 29, no. 1 (1987), 56. Retrieved from https://ces.to/vCfPbj. 
us about the kings' participation in brick production and in building, where it describes for us the steps of producing clay, explaining how Gudea (2144-2124 $\mathrm{BC}$ ) took the clay from his stirring place, late in the basket, and brought it to the brick template. ${ }^{32}$ At the same time this tradition where the king took part in the construction continues to this day, where at every important construction, an important person from office will come to lay the cornerstone of the building.

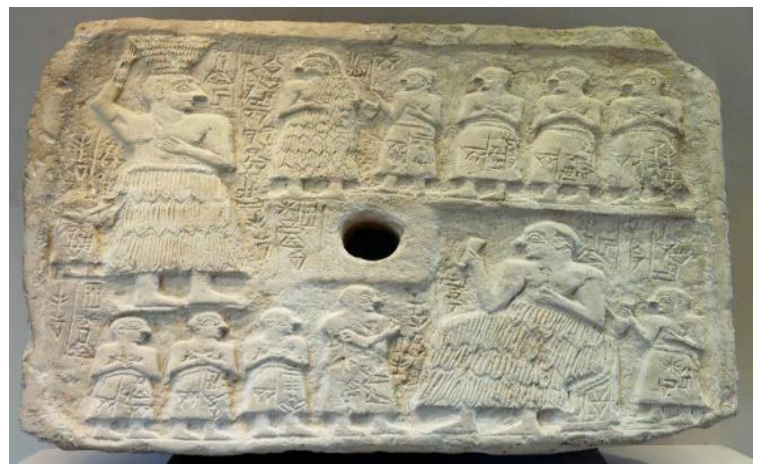

Figure 2. Ur-Nanshe Brings Clay in a Bascet

Source: Lloyd, The Archaeology of Mesopotamia, 134.

"XVIII: Gudea put the blessed water in the frame of the brick mould. (....) He set up the appropriate brick stamp so that (the inscribed side) was upwards (?): he brushed on honey, butter and cream (?), he mixed ambergris and essences from all kind of trees into a paste. He raised the impeccable carryingbasket and set it before the mould. Gudea put the clay in the mould, he acted precisely as prescribed, and behold he succeeded in making a most beautiful brick for the house.

(....) XIX: He struck the brick mould: the brick emerged into the daylight. He looked with complete satisfaction at the stamp (impression) on the clay (...) (Gudea) raised the brick out of the frame of the mould: he caried the brick- a lovely tiara (?) which reached up to heaven- and went among his people."33

32. Rashid, "Brick production in Ancient Iraq," 37.

33. Martin Sauvage, La brique et sa mise en oeuvre en Mésopotamie, des origines à l'époque achéménide (Brick and its implementation in Mesopotamia, origins at the time Achaemenid) (Paris: Research editions on civilizations, 1998), 22. 


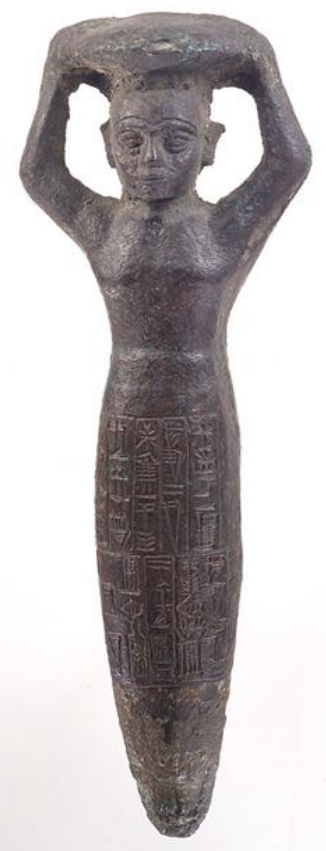

Figure 3. Ur-Nammu Brings Clay in a Bascet

Source: Sauvage, "La construction royale en Mésopotamie," figure 1.

Analytical research showed that the best clay to produce brick, was clay with an equal amount of silt to the amount of sand. But such clay was not available in all parts of Mesopotamia, so they used river mud to produce bricks. But one problem was that the amount of river mulch was more than the amount of sand and therefore hay and animal waste was added to the bricks during processing and one brick could keep with another brick. ${ }^{34}$ And changing the amount of mud in the clay from one place to another resulted in a change in the dried and burnt mud depending on the mud.

The basic method used to produce the brick is a manual method. This method is considered to be the oldest brick production method that is contained in cultivated land. Water is added to it, stirred and folded with hands and feet until it becomes identical sticky material that can be manually cut, drying late under the sun. After drying the bricks in the sun, they were moved to the furnace, and burned. ${ }^{35}$ It can be said that the availability of raw materials to produce bricks in different places in Mesopotamia was the element which helped in the emergence of such types of production, as well as the susceptibility of the raw material to keep up with the evolution of production processes that do not need a high level of technical skills and competency. Dry brick manufacturing sites were usually at the place they

34. Rashid, "Brick production in Ancient Iraq," 44.

35. Hussain, "Ways to produce bricks and its type," 259. 
wanted to build- it was called in Sumerian as (E.IM.DU.8/A) means exactly (house), and we have evidence written on it from a building called Akitu house:

"agurti sa libnati ina lab -bit a- biti ilabbinu"

Employee produces brick house at the gates Akitu. ${ }^{36}$

As we know, places of bricks production were situated near to construction sites because otherwise it could be more of a possibility to lose those bricks while transporting them. To light the stove for burned brick that was produced at the city walls, the animal waste kiln was used.

The production time of dried bricks and fired bricks was from mid-March until mid-October, because in this period the temperature is higher and there is no rain, so clay does not absorb moisture. In Sumerian language the month from which the brick cut starts is called the month of brick placement in Templates.

From the plaques written by cuneiform we have learnt that the time needed to dry the brick was one day or two days ${ }^{37}$ in the period marked for brickwork. And the time of fermentation of clay is one day. Furthermore, we have discovered that water which is used to make the bricks must be cleaner than that used to prepare the dried brick. ${ }^{38}$

There were two types of templates used in the manufacture of dried and fired bricks: the first is a hollow rectangular frame, of identical height and width. Moreover, the second type is an unmodeled template of its size as well as the size of the dried or burnt brick that they want to produce..$^{39}$ Bricks that permitted the scribing of letters in cuneiform proved difficult to detach from their templates, as proven by documented evidence found describing the use of water on the templates, before the brick was pressed, so as not to glue it in the templates. ${ }^{40}$ Indeed, the described manner of production of bricks referred to above, with scribed symbols is very slow and not economical, so they replaced them by using stamped stamps on the bricks to cover the desired script. The stamp used for the inscription of dried bricks -from the times of the Akkadian king Naramsin (Figure 4). It is translated as:

"Naramsin builder, the temple of Gad Inana."41 However, in this way a lot of brick was lost from the pressure of the seal, therefore they started to write by

36. Rashid, "Brick production in Ancient Iraq," 36.

37. Rashid, 45.

38. Rashid, 40.

39. Rashid, 45.

40. Rashid, 40.

41. Rashid, 41 
hand on the bricks as long as they were soft (Figure 5). The burned brick contained the following hand-made inscription.

Translation:

"For God Ninkesh Zaida, built Gudea, the king of Legash (Temple of God Ningirsu, in Kosu city)."42

This technique was applied to some quantities of brick, as a means of describing the history of the building and honoring its builders.

One of the most important aspects of the brick product obtained through these means of production were the properties resulting from the essence of the stage of the production process.

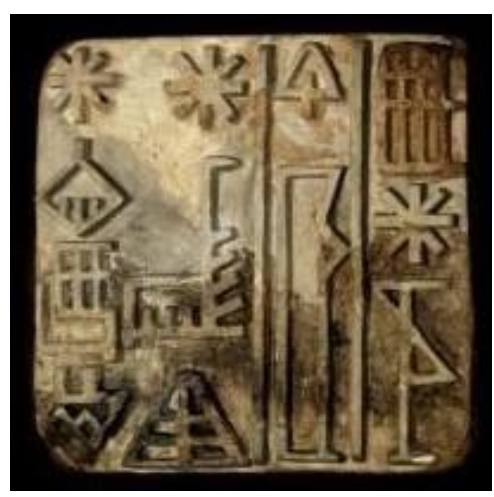

Figure 4. The Stamp Used for Inscription of Dried Bricks-from the Times of the Akkadian King Naramsin

Source: Rashid, "Brick production in Ancient Iraq," 41.

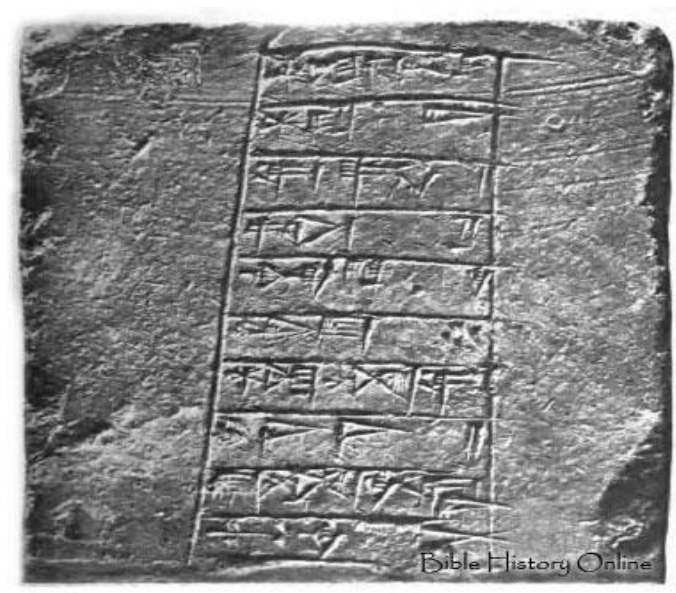

Figure 5. The Burned Brick with Hand-made Inscription

Source: Rashid, "Brick production in Ancient Iraq," 41.

Masonry is a heterogeneous material, and therefore its compressive strength depends on the strength of the components: brick, mortar and brick-

42. Rashid. 
mortar interface. Compressive strength is strongly influenced by the characteristics of the raw material and by the production process. It is known that the raw clay of old brick was often of low quality and the manufacturing process was relatively primitive and inefficient. Existing old bricks can provide an indication of their compressive strength, alongside other characteristics such as their mineral composition, texture, crack pattern and porosity level, thus revealing the conditions of drying and firing.

On the other hand, the evaluation of the mechanical strength of bricks belonging to old buildings is often difficult due to the high variability in production and additional variability caused by deterioration from the weather or chemical agents such as soluble salts, freeze-thawing cycles or load-unload cycles. A wide range of compressive strengths was reported by Fernandes on clay bricks from six monasteries in Portugal that were built between the 12th and 18th centuries. Therefore, environmental actions and deterioration might have influenced the results obtained. The values range from 6.7 to $21.8 \mathrm{MPa}$ and exhibit a very high coefficient of variation (up to $60 \%$ ). ${ }^{43}$ Most studies indicate low values for compressive strength and a large dispersion of the values, with coefficients of variation ranging between 25 and $55 \%$; but unusual strengths, higher than $50 \mathrm{MPa}$, were reported by Pauri et al. ${ }^{44}$

Modulus of Elasticity, significant differences have even been found between values proceeding from distinct studies of the same monument, which confirm the difficulty in defining this parameter. Moreover, it is not always clear how authors measured the values presented, even if most standards refer to the use of the linear part of the stress-strain curve in a range of $30-50 \%$ of the maximum stress value. The values found range from 1 to $18 \mathrm{GPa}$, which represents a range between 125 and 1,400 $\mathrm{f} \mathrm{c}$, where $\mathrm{f} \mathrm{c}$ is the compressive strength. Most common values are in the range of $200 \mathrm{f} \mathrm{c}$, with an average value of $350 \mathrm{f} \mathrm{c}$.

Tensile Strength, under the conditions of tensile stresses, indicates that clay bricks behave similarly to other quasi-brittle materials such as concrete or stone. Tensile strength depends mostly on the strength of mineral grains and of the matrix that binds them. Additionally, there is some dependence on the chemical composition, inclusions and the amount and dimension of pores. Because the strength depends heavily on the weaker zones, homogeneous raw clay with fewer impurities provide higher tensile strength.

43. Fernandes, Evaluation of two novel NDT techniques. Microdrilling of clay bricks and ground penetrating radar in masonry (PhD diss., University of Minho, 2006).

44. Marco Pauri, Antonia Stazi, F. Mastrosanti, and Marco D'Orazio, "The Decay of Ancient Building masonry, a case study" (presentation, 10th International Brick/Block Masonry Conference, Calgary, 1994). 
Raw clay can be characterized by means of chemical and mineralogical studies. ${ }^{45}$ These are frequent Fernandes et al. The determination of the chemical composition of old bricks allow the identification of possible deficiencies that occurred during their production, like the presence of organic matter, lime nodules, harmful soluble salts and other impurities that might adversely affect the durability of the brick. ${ }^{46}$

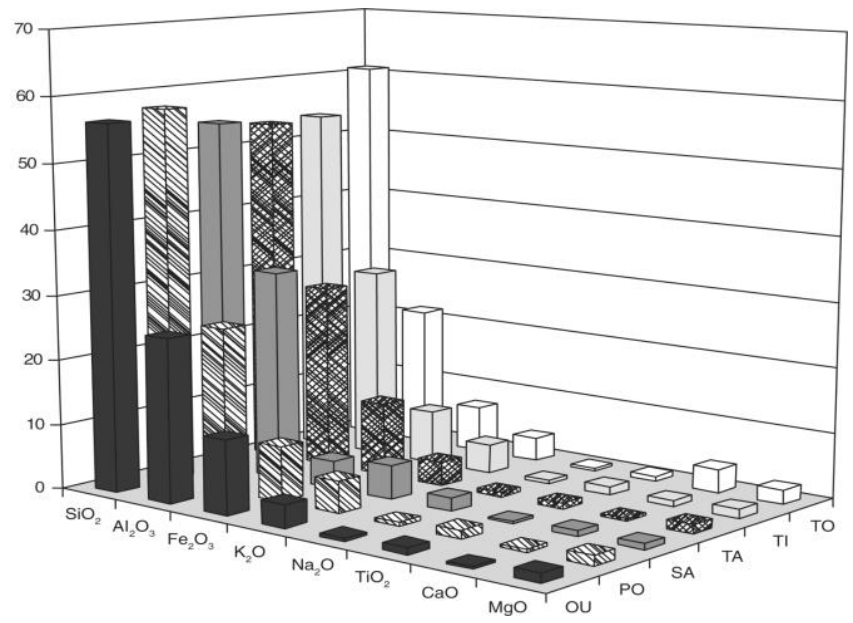

Figure 6. Average Proportion of the Principal Chemical Components of Old Clay Bricks

Source: López-Arce et al., "Bricks in historical buildings of Toledo City".

Chemical oxides commonly found in clay bricks (Figure 6) are the following: silica ( $\mathrm{SiO} 2)$, alumina (Al2O3), iron (Fe2O3) or ferrous oxide ( $\mathrm{Fe} 3 \mathrm{O} 4)$, potassium oxide $(\mathrm{K} 2 \mathrm{O})$, titanium dioxide $(\mathrm{TiO} 2)$ as well as sodium $(\mathrm{Na} 2 \mathrm{O})$, calcium $(\mathrm{CaO})$ and magnesium $(\mathrm{MgO})$ oxides. Silica and alumina constitute the base elements of clay and are usually found in the following proportions: about $50 \%$ for $\mathrm{SiO} 2$ and $15-20 \%$ for $\mathrm{Al} 2 \mathrm{O} 3$. Other components might be considered like barium (Ba), zirconium $(\mathrm{Zr})$, strontium $(\mathrm{Sr})$, rubidium $(\mathrm{Rb})$ and manganese $(\mathrm{Mn})$. However, these elements are always present in very small quantities and expressed in parts per million (ppm), while the proportion of the main components is expressed as a percentage of the material volume. Chemical composition can differ substantially in old bricks, with reports of clay bricks from the 12th to 13th centuries showing $38 \%$ of silica, $21.5 \%$ of alumina and $32.5 \%$ of ferrous oxide. ${ }^{47}$ Also, Moropoulou

45. Antonia Moropoulou, et al., "Weathering phenomena on the Hagia Sophia Basilica, Konstantinople," in Structural repair and maintenance of historical buildings III, ed. Carlos. A. Brebbia (Southampton, UK: WIT Press Publications, 1993), 61.

46. Gilbert Robinson, "Characterization of bricks and their resistance to deterioration mechanisms" (presentation, 10th International Brick/Block Masonry Conference, Calgary, 1994), 157.

47. Paula López-Arce, et al., "Bricks in historical buildings of Toledo City, characterization and restoration," Materials Characterization 50 (2003): 60. 
reported that the chemical composition of clay bricks from the Basilica of Hagia Sophia, exhibit a much higher proportion of silica (30-70\%) and a lower proportion of alumina (8-16\%) than normal clay bricks. ${ }^{48}$

\section{Types of Bricks}

The main types of bricks in Mesopotamia are the first (Riemchen) from which we can define as dried or burnt brick, which has its depth equal to its width, and its length twice the size of its width. Moreover, another kind is Planoconvex (Figure 7) and spun from the previous brick that is flat-convex in advance. It is made by adding more clay than the template size at the time of production and bending the brick from above. Simultaneously, Plano-convex brick was divided into two types, the difference between them was only in the brick's thickness - where the older type was thicker than the newest. ${ }^{49}$ The first was called "Cushion type" and the road is called "Biscuit type." The Plano-convex first appearance in building technology dates back to the 3rd millennium BC. This technique was using for nearly 1,000 years before it disappeared. The period in which the use of this kind brick disappeared coincides with the time when the Sumerians declined as a force reigning over the south of Mesopotamia. Therefore, we can say that the Plano-convex brick had a great significance in the Sumerian epoch, where it was used in all the buildings built at the time of their reign. In addition, it can be proved that this is somehow related to the brick traditions employed during the Sumerian Akkadian period, who ruled in the midexpensive 3rd millennium BC. Even though they did not use Plano-convex brick in any building from their reign, its popularity endured during the 3rd millennium BC.

2

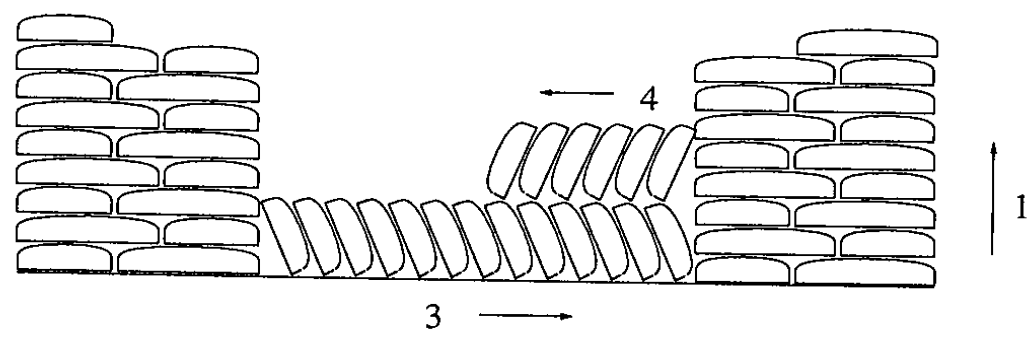

Figure 7. Brick Plano-Convex

Source: Delougaz, Plano Convex Bricks, 24.

From the plaques written we know various types of clay, dried bricks, and burned (Table 1).

48. Moropoulou, et al., "Weathering phenomena on the Hagia Sophia Basilica," 61.

49. Pinhas Delougaz, Plano Convex Bricks and the Methods of their Employment (Chicago: The University of Chicago Press, 1933), 2. 


\begin{tabular}{|l|c|c|}
\hline & Ancient Names & Translations \\
\hline 1 & IM. NITA & Soil/(clay) Man \\
\hline 2 & IM. MUNUS & Soil/(clay) Women \\
\hline 3 & IM. SAL. SAL & Soil/(clay) Thin \\
\hline 4 & IM. HI. HI & Good Clay Fermentation \\
\hline 5 & IM. RA. RA & Good clay \\
\hline 6 & IM. A. SUD & Clay covered with Water \\
\hline 7 & IM. KAL & The best types of burnt brick clay \\
\hline 8 & IM. MU. DU. A. & Brick fired with name \\
\hline 9 & IM. MU. MU. DU. A & Brick fired with name \\
\hline
\end{tabular}

Table 1. Names of Clays that Come from the Ancient Writing

According to Mr. Rashid ${ }^{50}$ if it comes to the name Clay Men and Women it is to mean its hardness and its ease, and clay thin name appeared from its name where it is translate $S A L$ as a female and in every place where we can see this stamp, it means female so we can translate it as a female clay or thin clay. Good Clay Fermentation was used to build dried brick, Good Clay for making burnt bricks was clay water spray and it was used in the building of bathroom and toilet facilities as well as in asphalt later.

\section{Chronological Evolution of Brick Shapes and Dimensions}

Throughout every time period in Mesopotamia the brick had no single form or identical or similar size, so it is not easy to determine the shape and dimensions of the brick throughout all the epochs in Mesopotamia. Sometimes in one time period there were different shapes and dimensions of the bricks discovered on excavation sites. One such example (Table 2) is bricks from the Eridu city (Figure 8$)^{51}$

\begin{tabular}{|l|c|c|c|}
\hline Layer & Lenght & Whide & Thickness \\
\hline 10 & 30 & 12 & 8 \\
\hline \multirow{3}{*}{} & 28 & 23 & 6 \\
& 28 & 22 & 6 \\
\hline \multirow{6}{*}{6} & 27 & 21 & 6 \\
\hline \multirow{3}{*}{ F Foundation } & 23 & 12 & 6 \\
& 23 & 17 & 6 \\
& 23 & 20 & 6 \\
\hline
\end{tabular}

Table 2. Dimensions of Dried and Burned Bricks (in cm) in Eridu City

50. Rashid, "Brick production in Ancient Iraq," 45.

51. Fouad Sefar, "Excavations in Eridu" [in Arabic], Sumer 5, no. 2 (1949): 163. 


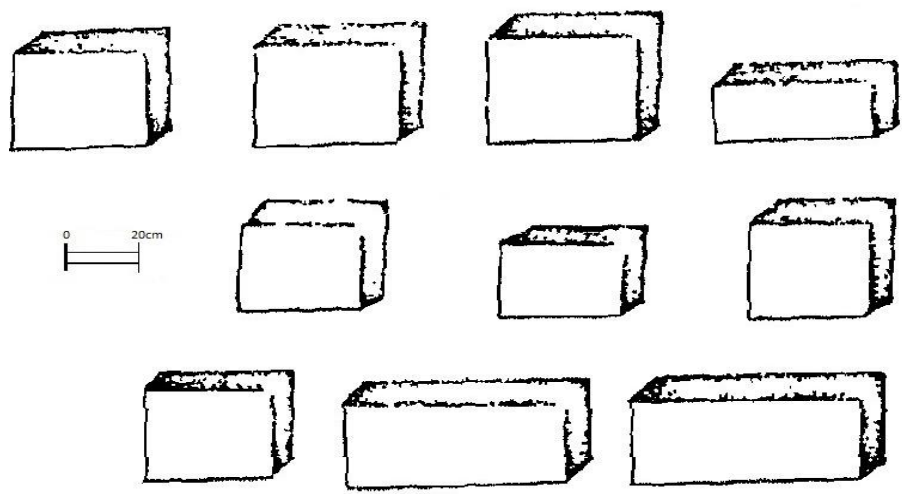

Figure 8. Dried Brick Shape and Fired

Source: Al-Temim, "Mud Bricks in Ancient Iraq," 278.

Thanks to the dimensional characteristics from Eridu we see the difference in dimension of the bricks during one particular time period, as well as the difference in layers. The excavations reveal that a rectangular brick was most popular in Eridu. At the same time, according to the researchers flat-convex brick, that each brick had its dimensions and between 23 bricks we found only two bricks of equal size and their dimensions are generally in between (31x22, 8x16 $\mathrm{cm}) .52$

The shape of the rectangular brick was the same in later periods (Table 3), but the dimensions change as in the Ubaidian period where the brick was measured $(44 \times 22 \times 8 \mathrm{~cm})$, and in the city of Eridu during the Uruk period when the brick dimension decreased to $(22 \times 11 \times 8 \mathrm{~cm})$. The shape of the brick as a rectangle did not last long, by the appearance of a square brick in the Akkadian period that lasted quite a long time in Mesopotamia..$^{53}$

The most suitable brick shape that can improve the way of joining the structure to make it stronger, as well as the ease of transport from the production site to the construction site, the choice the size of the brick which is used for the speed and hardness of the construction process, from the expensive side of the easy-to-carry brick to high buildings, and the purpose in which the fired bricks were used, the building of the basic structure of the buildings, the floor of the houses and the street pavilions, these elements were important elements that played a main role in determining the dimensions, size, and shape of the brick. At the same time these elements answer a lot of questions related to the nature of construction and production. They also emphasize prominence in many dimensions and sizes. Depending on the need and type of buildings and in accordance with the wealth and power of power in some authorities, led to a regular tendency and smaller brick.

52. Delougaz, Plano Convex Bricks, 2.

53. Rashid, "Brick production in Ancient Iraq," 35. 


\begin{tabular}{|c|c|c|c|c|}
\hline Period & Date & Site & $\begin{array}{l}\text { Dimensions } \\
\text { of Bricks-cm }\end{array}$ & $\begin{array}{l}\text { Amount of } \\
\text { the Bricks in } \\
\text { every } \mathrm{m}^{3}\end{array}$ \\
\hline Jarmo & & Village jarmo & Not found & \\
\hline Hassuna & $6800-5900$ & - & Not found & \\
\hline Halaf & $5900-5300$ & $\begin{array}{l}\text { Beginning of appe- } \\
\text { arance of the bricks }\end{array}$ & - & \\
\hline Ubaid & $5900-4200$ & Eridu & $\begin{array}{c}49 \times 26 \times 8^{54} \\
47 \times 22 \times 7 \\
44 \times 22 \times 8 \\
30 \times 12 \times 8 \\
46 \times 21 \times 5^{55} \\
42 \times 20 \times 8 \\
41 \times 22 \times 8 \\
23 \times 22 \times 6 \\
23 \times 17 \times 6 \\
32 \times 20 \times 6 \\
28 \times 23 \times 6 \\
28 \times 22 \times 6 \\
27 \times 21 \times 6 \\
\text { in foundation } \\
23 \times 19 \times 7 \\
42 \times 18 \times 6 \\
25 \times 21 \times 6\end{array}$ & $\begin{array}{c}80 \\
99 \\
101 \\
264 \\
126 \\
112,5 \\
112 \\
216 \\
288 \\
162 \\
168 \\
189 \\
210 \\
\\
220 \\
135 \\
240\end{array}$ \\
\hline Uruk & $4200-3100$ & Eridu & $\begin{array}{c}21 \times 12 \times 7^{56} \\
22 \times 11 \times 8 \\
26 \times 13 \times 7 \\
26 \times 14 \times 9 \\
29 \times 12 \times 8 \\
\end{array}$ & $\begin{array}{l}352 \\
405 \\
330 \\
252 \\
280 \\
\end{array}$ \\
\hline Jemdet Naser & $3100-2900$ & Not found by me & & \\
\hline Early Dynastic period & $2900-2340$ & Lagash-Tello & $36 \times 26 \times 6$ & 144 \\
\hline Akkadian period & 2340- 2159 & Nuffer & $38 \times 38 \times 7$ & 68,75 \\
\hline Old Babylonian period & $1894-1595$ & Babylon & $35 \times 35 \times 9$ & 81 \\
\hline $\begin{array}{l}\text { Middle Babylonian } \\
\text { period }\end{array}$ & $1500-1000$ & Dur-kurigalzu & $\begin{array}{c}32 \times 32 \times 10 \\
30 \times 30 \times 8\end{array}$ & $\begin{array}{c}72 \\
84,5 \\
\end{array}$ \\
\hline Neo-Assyrian & $1000-610$ & Ashur & $47 \times 47 \times 6$ & 48 \\
\hline Neo-Babylonian & $\begin{array}{c}1100 / 1000- \\
539 \\
\end{array}$ & Babylon & $\begin{array}{l}27 \times 27 \times 7 \\
36 \times 36 \times 7\end{array}$ & $\begin{array}{c}142,5 \\
99 \\
\end{array}$ \\
\hline
\end{tabular}

Table 3. The Dimensions of the Bricks in an Ancient Period

\section{Discussion}

The sizes of dried or burned bricks vary depending on the time and the place but as a rule of thumb regarding brick size in Mesopotamia, in most

54. Al-Taie, Al-Ansari, and Knutsson, "Progress of building materials," 224.

55. Sefar, "Excavators General Directorate of Antiquities in Eridu" [in Arabic], Sumer 3, no. 2 (1947): 225.

56. Al-Taie, Al-Ansari, and Knutsson, "Progress of building materials," 223. 
cases the width of the dried or burned brick is twice its thickness and its length is twice its width. Moreover, in some cases the width of the brick is the same as its thickness, but its length remains twice its width. Thanks to the differences in brick size we see in the plan, the following facts appear:

- At the beginning of different eras of ancient Mesopotamia, various dimensions of brick prevailed, generally characterized by many sizes. In the middle ages of the kingdom, it had brick dimensions of almost a meter long and a quarter meter wide $(49 \times 26 \times 8 \mathrm{~cm})$, in irregular shapes. Some of the bricks were likely to form flatly convex with dimensions $(23 \times 22 \times 6 \mathrm{~cm})$ and $(28 \times 23 \times 6 \mathrm{~cm})$. At the same time, rectangular bricks appeared in building foundations $(42 \times 18 \times 6 \mathrm{~cm})$. The size of brick used differs as techniques evolved to improve the standard of joining and durability of the walls, but the building was not fast enough.

- In the period of Uruk the brick tended to be a rectangular regular brick of smaller dimensions where it was almost half width, exemplified by the city Eridu where the brick measured $(21 \times 12 \times 7 \mathrm{~cm}),(22 \times 11 \times 8 \mathrm{~cm})$ and $(26 \times 13 \times 7 \mathrm{~cm})$, construction from this kind of bricks is faster and more regular than during the Ubaid period.

- In the Early-dynastic period, we see that the width of the brick increases and avoiding the rule of brick width is also twice its length example in this position Tello.

- During the Akkadian period the size of the brick measured increased (38x38x7 $\mathrm{cm})$, and also in the Neo Assyrian period where the largest brick in ancient Mesopotamia appeared $(47 \times 47 \times 6 \mathrm{~cm})$, the brick increase can result from various reasons, among others, the strength and wealth of the authorities of those periods who used the brick in the casing of official buildings, and also in the city of Assyria, where it was used for centuries not regular stone to build, so the brick was enlarged.

- Since the Akkadian period, quaternary bricks have appeared in various dimensions in which was easier to build and stronger, lasting until the end of the Ottoman Empire in Iraq. The beginning of diminishing bricks in Neo Babylon was $27 \times 27 \times 7 \mathrm{~cm}$, and we can say that this change in brick size has occurred because it was tailored to the speed of construction, facilitating its transport from the production site to the construction site, and reducing the damage and cost of the brick.

- In the entire history of Mesopotamia, there was no cubic shaped brick, which indicates that the ancient inhabitants of Iraq found that the brick which was less than the width of the thickest was the best to build with in Mesopotamia.

\section{Conclusion}

The history of the brick is almost as long as the history of human civilization. The brick is an invaluable building material used in centuries old traditions, going back to the beginning of sedentary lifestyle of ancient people. By observing the creative process and evolution of the brick, the ways of using of it, the choice of finishing methods and the types of grain used in its production, we learn more about these these ancient peoples, their needs, the ways they responded to meet 
their needs and the environmental conditions of their lives. Besides the population that settled there permanently, we learn of the development of agriculture that appeared, the demand for durable housing: -the kind could protect people from the weather, climate and wild animal attacks. The environmental conditions of Mesopotamia and changing the way of people's life were main enabler ouch evolutions machine -in the sphere of construction and in this way to improving life. In the sometime with bricks appears also durable writing medium -clay tablets with cuneiform- today invaluable source of knowledge for us. Over time they started to use enamel and decorate the buildings with coloured elements, whilst mosaics also appeared during this epoch. The most precious source of information for us turns out to be the shape and size of bricks. They are characteristic for every period in the history of the civilization of the Sumerian King. And follow this way -as it turns out- using the specific size of bricks, their shape, fiber composition for built -were some kind of habit or tradition in Mesopotamians reality. The parameters scientifically so that they were reflection of the power of the ruling, as well as the fit to construction speed, the manner of transport and destiny of building. Throughout history, methods of brick production have improved, the experience of various civilizations disseminate to gradually, however the firsts-the original methods of production were using still.

\author{
Abbreviatios \\ MPa: Uniaxial compressive strength. \\ GPa: Modulus of Reference elasticity. \\ F c: Fracture Compression.

\section{Bibliography} \\ Abd Alrazaq, Najel K. "The planning and design characteristics of buildings and \\ mud settlements in Iraq" [in Arabic]. Journal Planner and Development 25 \\ (2012): 93-111. \\ Al-Taie, Entidhar, Nadhir Al-Ansari, and Sven Knutsson. "Progress of building \\ materials and foundation engineering in ancient Iraq." Advanced Materials \\ Research 446-449 (2012): 220-41. \\ Al-Temimi, Abas A. "Mud Bricks in Ancient Iraq, Production and Patterns" [in \\ Arabic]. Sumer 38 (1982): 276-83. \\ Alrwishdi, Seaid. "Caves in the Middle East" [in Arabic]. Sumer 25 (1969): 252-72. \\ Aurenche, Olivier. La Maison Orientale, L'architecture du proche orient ancien des \\ origines au milieu du quatrieme millenaire (The Oriental House, The architecture of
}


the ancient Near East origins in the middle of the fourth millennium). Paris: French Institute of Archeology of the Middle East; Beirut, Damascus Amman: Archaeological and Historical Library, 1981.

Canby, Jeanny Vorys. "A Monumental Puzzle Reconstructing the Ur-Nammu Stela." Expedition 29, no. 1 (1987): 54-64. Retrieved from https://ces.to/vCfPbj.

Dalkılıç, Neslihan, and Adnan Nabikoğlu. "Traditional manufacturing of clay brick used in the historical buildings of Diyarbakir." Frontiers of Architectural Research 6, no. 3 (2017): 346-59.

Delougaz, Pinhas. Plano Convex Bricks and the Methods of their Employment. Chicago: The University of Chicago Press, 1933.

Ellis, Richard S., Foundation Deposits in Ancient Mesopotamia. New Haven Londres: Yale University Press, 1968.

Fernandes, Francisco M., Paulo B. Lourenço, and Fernando Castro. "Ancient Clay Bricks: Manufacture and Properties." In Materials, Technologies and Practice in Historic Heritage Structures, edited by Maria Boştenaru Dan and Richard Přikryl. Dordrecht: Springer, 2010.

Fernandes, Francisco M. Evaluation of two novel NDT techniques. Microdrilling of clay bricks and ground penetrating radar in masonry. PhD diss., University of Minho, 2006.

Finkbeiner, Uwe. "Uruk-Warka, Evidence of the Gamdat Nasr Period." In Gamdat Nasr: Period or Regional Style?, edited by Uwe Finkbeiner and Wolfgang Röllig, 33-56. Wiesbaden: Reichert, 1986.

Frankfort, Henri. The Art and Architecture of the Ancient Orient. Chicago: Penguin Books, 1970.

Gür, N. Volkan, Ömer Ş. Deniz, and Savas Ekinci. "Carrier Materials and Components in Masonry Masonry." Paper presented at the 6th National Roof \& Facade Symposium, Faculty of Engineering and Architecture, Uludağ University, Bursa, Turkey, April, 2012. Retrieved from https://bit.ly/30X9 sYG.

Hussain, Setar H. "Ways to produce bricks and its type" [in Arabic]. Sumer 43, no. 1 (1984): 258-65.

Kozlowski, Stefan K., and Andrzej Kempisty. "Architecture of the Pre-Pottery Neolithic Settlement in Nemrik, Iraq." World Archaeology 21, no. 3 (1990): 34862.

Lloyd, Seton. The Archaeology of Mesopotamia, From the Old Stone Age to the Persian Conquest. Translated by Al-Ahmed Samy. Baghdad: Notional Hause Production, 1980.

López-Arce, Paula, Javier Garcia-Guinea, Mercedes Gracia, and Joaquin Obis. "Bricks in historical buildings of Toledo City, characterization and restoration." Materials Characterization 50 (2003): 59-68.

Moorey, Peter Roger Stuart. Ancient Mesopotamian Materials and Industries, The Archaeological Evidence. Oxford: Clarendon Press, 1994. 
Moropoulou, Antonia, Basile Christaras, G. Lavas, George Penelis, N. Zias, Guido Biscontin, E. Kollias, et al. "Weathering phenomena on the Hagia Sophia Basilica, Konstantinople." In Structural repair and maintenance of historical buildings III, edited by Carlos. A. Brebbia, 47-66. Southampton, UK: WIT Press Publications, 1993.

Mustava, Mohammed Ali, and Seaid Alrwishdi. Fired brick production [in Arabic]. Baghdad: General Directorate of Ancient Monuments, 1992.

Oates, David. "Innovations in Mud-Brick, Decorative and Structural Techniques in Ancient Mesopotamia." World Archaeology 21, no. 3 (1990): 388-406.

Oates, Joan. "The Choga Mami Transitional." In La Prehistoire de la Mesopotamie, edited by Jean-Louis Huot, 163-80. Paris: Editions du CNRS, 1987.

Pauri, Marco, Antonia Stazi, F. Mastrosanti, and Marco D'Orazio. "The Decay of Ancient Building masonry, a case study." Paper presented at the 10th International Brick/Block Masonry Conference, Calgary, 1994.

Powell, Marvin A. "Metrological Notes on the Esagila Tablet and Related Matters, Appendix II, Bricks as Evidence for Metrology." Zeitschrift fur Assyriologie 72 (1982): 116-23.

Rashid, Fuozi. "Brick production in Ancient Iraq" [in Arabic]. Oil and Development, Development in Iraq for Centuries 87 (1981): 33-46.

Ren, Kebao B., and Douglas A. Kagi. "Upgrading the durability of mud bricks by impregnation." Build Environment 30, no. 3 (1995): 433-40.

Robinson, Gilbert. "Characterization of bricks and their resistance to deterioration mechanisms." Paper presented at the 10th International Brick/Block Masonry Conference, Calgary, 1994.

Salonen, Armas. Die Ziegeleien im alten Mesopotamien (The brickworks in ancient Mesopotamia). Helsinki: Finnish Academy of Sciences, 1972.

Sauvage, Martin. "Les briques de grande taille à empreintes de doigts: le Choga Mami Transitional et la culture de Oueili" (Large bricks with fingerprints: the Choga Mami Transitional and the culture of Oueili). In Études mésopotamiennes: Recueil de textes offert à Jean-Louis Huot (Mesopotamian Studies: A collection of texts offered to Jean-Louis Huot), edited by Catherine Képinski and Christine Brenniquet, 417-47. Paris: ERC, 2001.

Sauvage, Martin. "La construction royale en Mésopotamie: ingénierie, administration et propagande" (Royal construction in Mesopotamia: engineering, administration and propaganda). ArchéOrient-Le Blog. May 27, 2016 [In French]. Retrieved from https://ces.to/ll3BHw.

Sauvage, Martin. La brique et sa mise en oeuvre en Mésopotamie, des origines à l'époque achéménide (Brick and its implementation in Mesopotamia, origins at the time Achaemenid). Paris: Research editions on civilizations, 1998).

Sefar, Fouad. "Excavations in Eridu" [in Arabic]. Sumer 5, no. 2 (1949): 159-74.

Sefar, Fouad. "Excavators General Directorate of Antiquities in Eridu" [in Arabic]. Sumer 3, no. 2 (1947): 219-36. 
Verhoeven, Ursula. "Eine technologische Rarität. Das Brennen von Ziegeln in der Grabdekoration des Mittleren und Neuen Reiches" (A technological rarity. The burning of bricks in the grave decoration of the Middle and New Kingdom). Communications of the German Archaeological Institute, Department of Cairo 43 (1987): 259-66.

Wijffels, Tomas, and G. Nijland Timo. "Deterioration of historic brick masonry due to combined gypsum, ettringite and thaumasite, a case study." Paper presented at the 13th International Brick/Block Masonry Conference, Amsterdam, 2004.

Yavuz, Aysil Tukel. "The Relationship between Materials and Architecture in the Seljuk Period." Paper presented at the Material and Architecture Symposium in Anatolia from the Past to the Future, UIAXXII World Architecture Congress, 2005. 
